\title{
Impact of I/D polymorphism of angiotensin-converting enzyme (ACE) gene on myocardial infarction susceptibility among young Moroccan patients
}

\author{
Wiam Hmimech ${ }^{1 \dagger}$, Hind Hassani Idrissi ${ }^{*^{*}+}$, Brehima Diakite ${ }^{1}$, Farah Korchi ${ }^{2}$, Dalila Baghdadi ${ }^{2}$, \\ Hind Tahri Joutey Hassani Idrissi², Meriem Haboub², Rachida Habbal ${ }^{2}$ and Sellama Nadifi'
}

\begin{abstract}
Objective: Our case-control study aimed to access the potential association of insertion/deletion (I/D) ACE (angiotensin converting enzyme) gene polymorphism with myocardial infarction (MI) risk of occurrence among a sample of Moroccan patients, especially young ones.

Results: Distribution of I/D ACE gene variant among cases vs controls, showed that healthy controls carried out higher frequency of wild type allele I compared to cases (23.5\% vs $21.79 \%$ respectively), when cases were carrying higher frequency of mutant allele D (78.21\% vs $76.5 \%$ for controls). Patients were-after this- divided into two groups of $<45$ and $>55$ years of age, to investigate whether or not younger patients carried out higher frequency of the mutant allele $\mathrm{D}$, than older ones. As expected, $<45$ years old patients carried out more DD genotype than older ones (68.9\% vs $54.6 \%$ respectively), and higher frequency of mutant allele $D(81.08 \%$ vs $75 \%$ respectively). Besides, a tendency to a positive association was found under the recessive genetic transmission model $(\mathrm{OR}[95 \% \mathrm{Cl}]=1.85$ [0.93-3.69], $\mathrm{P}=0.08$ ), suggesting that the I/D ACE polymorphism may be associated with Ml occurrence among younger patients ( $<45$ years of age).
\end{abstract}

Keywords: Insertion/deletion (I/D) ACE (angiotensin converting enzyme) gene polymorphism, Myocardial infarction (MI), Genetic susceptibility, Moroccan patients

\section{Introduction}

Myocardial infarction (MI) has always been considered as the most severe complication of coronary artery disease (CAD) worldwide. As being a complex and multifactorial disease, $\mathrm{MI}$ involves the interaction of environmental and genetic components [1]. Till now, a wide range of genetic polymorphisms was analyzed for their association with MI risk, such as eNOS gene (endothelial nitric oxide

\footnotetext{
*Correspondence: hassani-idrissi-hind@hotmail.fr

tWiam Hmimech and Hind Hassani Idrissi contributed equally to this work

${ }^{1}$ Laboratory of Genetics and Molecular Pathology, Medical School, University Hassan II, 19, Street TariklbnouZiad, B. P: 9154, Casablanca, Morocco

Full list of author information is available at the end of the article
}

synthase), PAI-1 (plasminogen activator inhibitor type 1), APOA5 (apo-lipoprotein A5), MTHFR (methylene tetra hydrofolate reductase), FII prothrombin, FV leiden and FV Casablanca [2-4], and also gene modulating response to treatment [5-7].

Among the most studied genes is angiotensin converting enzyme (ACE) gene, mapped on chromosome 17q23 (Additional file 1: Figure S1) [8-10]. The gene sequence is composed of 26 exons and 25 introns. The product is a membrane protein involved in hypertension and CAD development [11]. It has been demonstrated that ACE high level was associated with risk of vascular resistance and high blood pressure events, resulting from hyper synthesis of angiotensin II (vasoconstrictor agent) [12]. Angiotensin II is also known to be an essential regulator 
of proliferation, migration and hypertrophy of vascular smooth muscle cells, increasing thus its association with CAD and MI risk of occurrence [13]. Many SNPs have been described in ACE gene. Interestingly, the insertion/ deletion (I/D) in intron 16 was the most investigated. It's characterized by the insertion or deletion of a 287 noncoding base pair Alu repeat sequence (dbSNP rs4646994), and has been correlated with circulating ACE, intracellular and heart tissue levels [14]. It was reported that DD genotype carriers had increased ACE plasma levels compared to II genotype carriers $[15,16]$. Association of I.D ACE polymorphism and MI predisposition has been extensively investigated, but results were divergent and controversial [11].

The main objective of our case-control study was to access whether I/D polymorphism of ACE gene may be associated with susceptibility to MI in a sample of Moroccan $<45$ and $>55$ years of age, compared to healthy controls.

\section{Main text Methods}

Blood samples were collected from 140 unrelated (MI) patients, recruited from the Department of Cardiology, University Hospital Ibn Rochd, Casablanca, Morocco. The control group consisted of 182 unrelated and apparently healthy subjects, with no symptoms of Coronary Artery Disease. Clinical data concerning risk factors and biological parameters were collected for each patient in our study, and an informed consent was developed for both patients and controls. Venous blood from all participants in this study was collected in EDTA tubes. Genomic DNA was extracted from whole blood leukocytes using the salting-out method as previously described by Miller et al. [17].

We used PCR (Polymerase Chain Reaction) to genotype DNA samples for the I/D ACE polymorphism, as previously described by Lindpaintner et al. [18]. Genotyping was performed by amplification from 50 to 100 ng of genomic DNA. PCR gave rise to three profiles: homozygous wild type II (one fragment of $490 \mathrm{pb}$ ), ID heterozygous (two fragments of 490 and $190 \mathrm{bp}$ ), and homozygous mutant DD (one fragment of $190 \mathrm{pb}$ ). The amplified products were separated on $3 \%$ agarose gel electrophoresis stained with ethidium bromide (BET), and visualized with UV rayons.

Statistical analysis was performed using SPSS 21 . We used Chi square test ( $\chi 2)$ to evaluate the statistical significance of association between genotypes and classical risk factors. Hardy-Weinberg Equilibrium test (HWE) was performed in both cases and controls groups for the analyzed polymorphism. Odds ratio (OR) were calculated to estimate the association between genotypes and MI risk, with a confidence interval (CI) of $95 \%$. Significance was approved at $\mathrm{P}$ value less than 0.05 .

\section{Results}

I/D ACE polymorphism distribution was in HWE among cases but not controls (Additional file 1: Table S1). Most of our patients were male $(62.86 \%)$, aged $<45$ years of age (76 patients) or $>55$ years (66 patients).

Correlation between I/D ACE genotypes and MI risk factors showed was statistically positive with 'Obesity', with a tendency to a significant association with 'gender' $(\mathrm{P}=0.01$ and 0.06 respectively) (Table 1$)$.

We've analyzed the same correlation of risk factors and I/D ACE polymorphism distribution, this time among patients $<45$ years of age. No statistically significant association was found (Additional file 1: Table S2).

Table 2 shows the allelic and genotypic distribution of I/D ACE polymorphism among cases compared to controls. There was more homozygous wild type profile II among controls than cases ( $8.8 \%$ vs $5.7 \%$ respectively), but more heterozygous ID among cases than controls (32.2\% vs $29.1 \%$ for controls); no difference was found

Table 1 Traditional risk factors vs I/D ACE genotypes distribution among MI cases

\begin{tabular}{|c|c|c|c|c|}
\hline & \multicolumn{3}{|c|}{ MI cases $(\mathrm{N}=140)$} & \multirow[t]{2}{*}{$P$ value $(<0.05)$} \\
\hline & II n (\%) & ID n (\%) & DD n (\%) & \\
\hline Age (years) & & & & 0.1 \\
\hline$<45$ & $5(6.8)$ & $18(24.3)$ & $51(68.9)$ & \\
\hline$>55$ & $3(4.5)$ & $27(40.9)$ & $36(54.6)$ & \\
\hline Gender & & & & 0.06 \\
\hline o & $6(6.8)$ & $22(25)$ & $60(68.2)$ & \\
\hline 우 & $2(3.8)$ & $23(24.3)$ & $27(51.9)$ & \\
\hline Hypertension & & & & 0.3 \\
\hline Yes & $1(1.9)$ & $17(32.7)$ & $34(65.4)$ & \\
\hline No & $7(8)$ & $28(31.8)$ & $53(60.2)$ & \\
\hline Diabetes & & & & 0.5 \\
\hline Yes & $4(8.9)$ & $14(31.1)$ & $27(60)$ & \\
\hline No & $4(4.2)$ & $31(32.6)$ & $60(63.2)$ & \\
\hline Smoking & & & & 0.9 \\
\hline Yes & $4(6.6)$ & $19(31.1)$ & $38(62.3)$ & \\
\hline No & $4(5.1)$ & $26(32.9)$ & $49(62)$ & \\
\hline Obesity & & & & $0.01^{*}$ \\
\hline Yes & $3(12)$ & $13(52)$ & $9(36)$ & \\
\hline No & $5(4.4)$ & $32(27.8)$ & $78(67.8)$ & \\
\hline Dyslipidemia & & & & 0.6 \\
\hline Yes & $1(2.9)$ & $12(34.3)$ & $22(62.8)$ & \\
\hline No & $7(6.7)$ & $33(31.4)$ & $65(61.9)$ & \\
\hline Familial history of CVD & & & & 0.6 \\
\hline Yes & $0(0)$ & $4(40)$ & $6(60)$ & \\
\hline No & $8(6.2)$ & $41(31.5)$ & $81(62.3)$ & \\
\hline
\end{tabular}

* Statistically significant 
Table 2 Allelic and genotypic distribution of I/D ACE polymorphism among cases and controls

\begin{tabular}{lccll}
\hline & $\mathbf{N}=\mathbf{1 4 0}$ & $\mathbf{N}=\mathbf{1 8 2}$ & OR [95\% Cl] & P value \\
& Cases N (\%) & Controls N (\%) & & \\
\hline$\|$ & $8(5.7)$ & $17(8.8)$ & 1 & \\
ID & $45(32.2)$ & $52(29.1)$ & $1.84[0.73-4.66]$ & 0.2 \\
DD & $87(62.1)$ & $113(62.1)$ & $1.64[0.67-3.97]$ & 0.27 \\
$\|^{b}$ & $8(5.7)$ & $17(8.8)$ & 1 & \\
ID + DD & $132(94.3)$ & $165(91.2)$ & $1.7[0.71-4.06]$ & 0.23 \\
$\|+$ ID & $53(37.9)$ & $69(37.9)$ & 1 & \\
DD & $87(62.1)$ & $113(62.1)$ & $1[0.64-1.58]$ & 0.99 \\
I allele & $61(21.79)$ & $86(23.5)$ & 1 & \\
D allele & $219(78.21)$ & $278(76.5)$ & $1.11[0.77-1.61]$ & 0.58 \\
\hline
\end{tabular}

${ }^{a}$ Recessive model

${ }^{b}$ Dominant model

c Additive model

between the two groups concerning the homozygous mutant DD (62.1\% for both groups). The transmission models showed no statistical difference between cases and controls (Dominant: OR $[95 \% \mathrm{CI}]=1.7[0.71-$ 4.06], $\mathrm{P}=0.23$; Recessive: OR $[95 \% \mathrm{CI}]=1[0.64-1.58]$, $\mathrm{P}=0.99$; Additive: $\mathrm{OR}[95 \% \mathrm{CI}]=1.11[0.77-1.61]$, $\mathrm{P}=0.58)$.

Doing the same correlation, this time between $<45$ and > 55 years of age patients, we found more DD among < 45 years patients than $>55(68.9 \%$ vs $54.6 \%$ respectively). The $\mathrm{D}$ allele was more frequent among $<45$ than $>55$ aged patients $(81.08 \%$ vs $75 \%$ respectively). No statistically significant association was found with genotypes or genetic transmission models, even there was a tendency to a positive correlation with the recessive model (OR [95\% CI] $=1.85$ [0.93-3.69], $\mathrm{P}=0.08$ ) (Table 3).

\section{Discussion}

Recent reports strongly support the contribution of genetic variations in the pathogenesis of cardiac disorders including myocardial infarction [19]. Angiotensin II produced by $\mathrm{ACE}$ is a vasoconstrictor agent, known by promoting smooth muscle cells proliferation and determining structural cardiac changes that could lead to myocardial necrosis and congestive heart failure [20]. Association of ACE with coronary heart diseases (CHD) risk of occurrence has been largely discussed [21].

In Morocco, this is the first case-control study investigating the potential correlation between I/D ACE gene polymorphism and susceptibility to myocardial infarction (MI). $140 \mathrm{MI}$ patients (76 patients $<45$ years of age and 64 that were $>55$ ), were compared to 182 healthy volunteers, showing no symptoms of heart diseases, in
Table 3 Allelic and genotypic distribution of I/D ACE polymorphism among $<\mathbf{4 5}$ years of age Ml patients

\begin{tabular}{|c|c|c|c|c|}
\hline & $\begin{array}{l}N=74 \\
<45 \text { years old } \\
N(\%)\end{array}$ & $\begin{array}{l}N=66 \\
>55 \text { years old } \\
N(\%)\end{array}$ & OR $[95 \% \mathrm{Cl}]$ & $P$ value \\
\hline$\|$ & $5(6.8)$ & $3(4.5)$ & 1 & \\
\hline ID & $18(24.3)$ & $27(40.9)$ & $0.4[0.08-1.89]$ & 0.24 \\
\hline DD & $51(68.9)$ & $36(54.6)$ & & \\
\hline$\|^{b}$ & $5(6.8)$ & $3(4.5)$ & 1 & \\
\hline$I D+D D$ & $69(93.2)$ & $63(95.5)$ & $1.52[0.35-6.63]$ & 0.57 \\
\hline$\|+1 \mathrm{D}$ & $23(31.1)$ & $30(45.4)$ & 1 & \\
\hline $\mathrm{DD}^{\mathrm{a}}$ & $51(68.9)$ & $36(54.6)$ & 1.85 [0.93-3.69] & 0.08 \\
\hline I allelec & $28(18.92)$ & $33(25)$ & 1 & \\
\hline D allele & 120 (81.08) & $99(75)$ & $1.43[0.81-2.53]$ & 0.22 \\
\hline
\end{tabular}

a Recessive model

b Dominant model

c Additive model

order to access whether this polymorphism is implicated in MI occurrence in Morocco.

Our results showed that correlation of clinical risk factors with I/D ACE polymorphism was positive with 'Obesity' factor $(\mathrm{P}=0.01)$; no more significant association was found with the other risk factors analyzed (Table 1). Reports studying the predisposition to MI have suggests that contribution of genetics as a risk factor for MI occurrence became stronger among younger individuals, having not yet any of the traditional risk factors, such as age, hypertension, dyslipidemia, diabetes and smoking [22]. Trying to test the validity of this suggestion among our studied sample of patients, we performed a statistical correlation between traditional risk factors cited above, with I/D ACE polymorphism distribution especially among $<45$ years of age patients (Additional file 1: Table S2). Our results reported no positive association of distribution of this polymorphism with analyzed risk factors among this age range of patients, which goes in accordance with the previous suggestions.

Distribution of I/D ACE gene variant among cases vs controls, showed that healthy controls carried out high frequency of wild type allele I compared to MI cases ( $23.5 \%$ vs $21.79 \%$ respectively), when cases were carrying higher frequency of mutant allele $\mathrm{D}$ than controls (78.21\% vs $76.5 \%$ respectively). On the statistical side, no significant difference was found between the two groups (P values $>0.05$ ) (Table 2). Patients were-after this- divided into two groups of $<45$ and $>55$ years of age, to access whether younger patients carried out higher frequency of the mutant allele $D$, than older ones (Table 3). As expected, $<45$ years old patients carried out more DD genotype than older patients $(68.9 \%$ 
vs $54.6 \%$ respectively), and higher frequency of mutant allele D ( $81.08 \%$ vs $75 \%$ respectively). Besides, a tendency to a positive association was found under the recessive genetic transmission model $(\mathrm{OR}[95 \% \mathrm{CI}]=1.85[0.93-$ 3.69 ], $\mathrm{P}=0.08$ ), suggesting that the I/D ACE polymorphism may be associated with MI occurrence among young patients ( $<45$ years of age). Unfortunately, on the statistical side, $P$ values were not significant $(>0.05)$. This may be explained by several factors, such as the limited size of analyzed sample, especially of younger patients (76 patients), the proof is that, when taking $<45$ years old patients alone, a tendency to a positive correlation with I/D ACE polymorphism distribution starts to appear $(\mathrm{P}=0.08)$.

Results about the association of this variant of ACE gene with predisposition to MI, are controversial and divergent. Many studies have reported that the DD genotype was associated with $\mathrm{MI}$ increased risk of occurrence [16, 19, 23-28], when others suggested the opposite [22, 29-33]. Study conducted by Gardemann et al. [22], reported that DD genotype of ACE gene was associated with Coronary atherosclerosis only among subjects with no classic risk factors, which matches our findings about the tendency of this genotype to be associated with increased risk of MI among individuals without previous classic risk factors ( $<45$ years of age group of patients).

By another side, there are reasons for cautioning against a direct effect of ACE on heart diseases risk: ACE polymorphisms are associated with ACE plasma activity, but not angiotensin II plasma levels [34, 35]. This may be explained by the fact that rennin is the rate limiting step in angiotensin II production, not ACE [36]. It has been suggested that angiotensin II can affect vascular smooth muscle growth in cell culture [37], however, only hyperplasia is observed in the presence of serum, otherwise, hypertrophy alone does not occur [38, 39].

Previous studies have described a positive correlation between ACE polymorphism and CHD [39-41]. However, these studies have been criticized by a series of opposite studies [32, 33, 42-44]. A large case-control study by Lindpainter et al. [42], has demonstrated no association of D allele with increased risk of ischemic heart disease or MI. The heterogeneity of these results may be explained by numerous factors: differences in the studied populations, or the incapacity to accurately separate cases from controls. In addition, differences between the patient series in the general risk status (diabetes, smoking, and hypertension) may influence the effect of $\mathrm{ACE}$ gene polymorphism as a predictor of CHD occurrence. Interestingly, a large meta-analysis has showed that the OR for MI to be associated with the ACE DD is 1.26 [45]. It's clear that such OR would require larger sample sizes to prove a significant association between
ACE polymorphism and risk of MI. in addition, as the frequency of the D allele in the Moroccan population appears to be relatively high (76.5\%), a lower predictive effect of the I/D ACE polymorphism in our population would not be surprising. This raises the question of whether this polymorphism is a useful marker to predict the individual risk of $\mathrm{MI}$ in a clinical setting.

\section{Limitations}

Our case control study is the first to access whether I/D ACE gene polymorphism may be associated with MI susceptibility in Moroccan population. Our results showed that this variant of ACE gene was not associated with MI risk among the total of analyzed patients (all ages included). However, when differentiating between $<45$ and $>55$ years of age patients, a tendency to a significant association between the mutant allele D and MI risk started to appear among the younger group of patients ( $<45$ years of age), clinical risk factors free. One of the limitations of our study is the low sampling. More studies including larger sample sizes and focusing on young patients especially may provide useful help to better understand the contribution of ACE polymorphisms in MI susceptibility.

\section{Additional file}

Additional file 1: Table S1. Hardy-Weinberg equilibrium (HWE) among cases and control. Table 2. Traditional risk factors vs I/D ACE genotypes distribution among $<45$ years of age MI patients. Figure S1. Cytogenetic Location of ACE gene.

\section{Abbreviations}

MI: myocardial infarction; I/D: insertion/deletion; ACE: angiotensin converting enzyme; *: significant; \%: percentage; Cl: confidence interval; HWE: HardyWeinberg Equilibrium; OR: odds ratio.

\section{Authors' contributions}

$\mathrm{WH}$ and $\mathrm{HHI}$ participated in the design of this study, drafted the manuscript, carried out the DNA extraction and the molecular genetic studies, participated in the interpretation of data and performed the statistical analysis. BD participated in the sequence alignment. FK, BD and TJHIH and HM carried out the patient recruitment and the clinical data collection. $\mathrm{RH}$ and $\mathrm{SN}$ are the directors of the study; they designed and coordinated the experiments. All authors read and approved the final manuscript.

\section{Author details}

${ }^{1}$ Laboratory of Genetics and Molecular Pathology, Medical School, University Hassan II, 19, Street TariklbnouZiad, B. P: 9154, Casablanca, Morocco.

${ }^{2}$ Department of Cardiology, University Hospital Center IbnRochd, Casablanca, Morocco.

\section{Acknowledgements}

A special acknowledgement is addressed to all members of the Laboratory of Genetics and Molecular Pathology (LGPM) at the Faculty of Medicine and Pharmacy, University Hassan II, Casablanca, and the staff of Cardiology services $\mathrm{CHU}$ Ibn Rochd Casablanca, for their contribution to this work.

\section{Competing interests}

The authors declare that they have no competing interests. 


\section{Availability of data and materials}

See the rest of tables and figures in additional files.

\section{Consent for publication}

Not applicable.

\section{Ethics approval and consent to participate}

The publication of this study was approved by the ethics committee of University Hassan II, Casablanca, Morocco. All of patients and controls have consented to participate in this research study.

\section{Funding}

None.

\section{Publisher's Note}

Springer Nature remains neutral with regard to jurisdictional claims in published maps and institutional affiliations.

Received: 25 July 2017 Accepted: 30 November 2017

Published online: 21 December 2017

\section{References}

1. Das SR, Alexander KP, Chen AY, et al. Impact of body weight and extreme obesity on the presentation, treatment, and in-hospital outcomes of 50,149 patients with ST-segment elevation myocardial infarction results from the NCDR (National Cardiovascular Data Registry). J Am Coll Cardiol. 2011;58:2642-50.

2. Idrissi HH, Hmimech W, Diakite B, Korchi F, Baghdadi D, Habbal R, Nadifi S. Association of G894T eNOS, 4G/5G PAl and T1131C APOA5 polymorphisms with susceptibility to myocardial infarction in Morocco. Meta Gene. 2016:9:56-61.

3. Hmimech W, Idrissi HH, Diakite B, Baghdadi D, Korchi F, Habbal R, Nadifi S. Association of C677T MTHFR and G20210A Fll prothrombin polymorphisms with susceptibility to myocardial infarction. Biomed Rep. 2016;5:361-6.

4. Hmimech W, Diakité B, Idrissi HH, Hamzi KH, Korchi F, Baghdadi D, Habbal R, Nadifi S. G2691A and C2491T mutations of FV gene and predisposition to myocardial infarction in Morroco. Biomed Rep. https://doi. org/10.3892/br.2016.768.

5. Idrissi HH, Hmimech W, El Khorb N, Akoudad H, Habbal R, Nadifi S. Does i-T744C P2Y12 polymorphism modulate clopidogrel response among Moroccan acute coronary syndromes (ACS) patients? Genet Int J.

6. Idrissi HH, Hmimech W, El Khorb N, Akoudad H, Habbal R, Nadifi S. Association of the C3435T multi-drug resistance gene-1 (MDR-1) polymorphism with clopidogrel resistance among moroccan acute coronary syndromes (ACS) patients. J Thromb Circ. 2016;2:115.

7. Idrissi HH, Hmimech W, El Khorb N, Akoudad H, Habbal R, Nadifi S. Polymorphisms of CYP2C19 in Moroccan acute coronary syndromes (ACS) patients: effect on clopidogrel response. BCM Res Notes. 2017:341-52.

8. Zintzaras E, Raman G, Kitsios G, Lau J. Angiotensin-converting enzyme insertion/deletion gene polymorphic variant as a marker of coronary artery disease: a meta-analysis. Arch Intern Med. 2008;168:1077-89.

9. Bonnici F, Keavney B, Collins R, Danesh J. Angiotensin converting enzyme insertion or deletion polymorphism and coronary restenosis: meta-analysis of 16 studies. BMJ. 2002;325:517-20.

10. Agema WR, Jukema JW, Zwinderman AH, van der Wall EE. A metaanalysis of the angiotensin-converting enzyme gene polymorphism and restenosis after percutaneous transluminal coronary revascularization: evidence for publication bias. Am Heart J. 2002;144:760-8.

11. Chen Y, Dong S, He M, Qi T, Zhu W. Angiotensin-converting enzyme insertion/deletion polymorphism and risk of myocardial infarction in an updated meta-analysis based on 34993 participants. Gene. 2013;522:196-205.

12. Murphey LJ, Gainer JV, Vaughan DE, Brown NJ. Angiotensin-converting enzyme insertion/deletion polymorphism modulates the human in vivo metabolism of bradykinin. Circulation. 2000;102:829-32.
13. Touyz RM, Schiffrin EL. Signal transduction mechanisms mediating the physiological and pathophysiological actions of angiotensin II in vascular smooth muscle cells. Pharmacol Rev. 2000;52:639-72.

14. Danser AH, Schalekamp MA, Bax WA, van den Brink AM, Saxena PR, Riegger GA, Schunkert $\mathrm{H}$. Angiotensin-converting enzyme in the human heart. Effect of the deletion/insertion polymorphism. Circulation. 1995:92:1387-8.

15. Mehri S, Baudin B, Mahjoub S, et al. Angiotensin-converting enzyme insertion/deletion gene polymorphism in a Tunisian healthy and acute myocardial infarction population. Genet Test Mol Biomark. 2010;14:85-91.

16. Cambien F. The angiotensin-converting enzyme (ACE) genetic polymorphism: its relationship with plasma ACE level and myocardial infarction. Clin Genet. 1994:46:94-101.

17. Miller SA, Dykes DD, Polesky HF. A simple salting out procedure for extracting DNA from human nucleated cells. Nucleic Acids Res. 1988;16:1215.

18. Lindpaintner K, Pfeffer MA, Kreutz R, et al. A prospective evaluation of an angiotensin-converting-enzyme gene polymorphism and the risk of ischemic heart disease. N Engl J Med. 1995;332:706-11.

19. Cambien F, Poirier O, Lecerf $\mathrm{L}$, et al. Deletion polymorphism in the gene for angiotensin-converting enzyme is a potent risk factor for myocardial infarction. Nature. 1992:359(6396):641-4

20. Malik FS, Lavie CJ, Mehra M, Milani RV, Re RN. Renin-angiotensin system: genes to bedside. Am Heart J. 1997;134:514-26.

21. Hamstein $A$, deFaire $U$, Walldius $G$, et al. Plasminogen activator inhibitor in plasma: risk for recurrent myocardial infarction. Lancet. 1987:2:3-9.

22. Gardemann A, Weib T, Schwartz O, et al. Gene polymorphism but not catalytic activity of angiotensin I-converting enzyme is associated with coronary artery disease and myocardial infarction in low-risk patients. Circulation. 1995;92:2796-9.

23. Petrovič D, Bregar D, Guzic-Salobir B, Skof E, Span M, Terzić R, Petrovič $M G$, Keber I, Letonja M, Peterlain B. Sex difference in the effect of ACE-DD genotype on the risk of premature myocardial infarction. Angiology. 2004;55(2):155-8.

24. Bautista LE, Ardila ME, Gamarra G, Vargas Cl, Arenas IA. Angiotensin converting enzyme gene polymorphism and risk of myocardial infarction in Colombia. Med Sci Monit. 2004:10(8):473-9.

25. Mata-Balaguer T, de la Herran R, Ruiz-Rejon C, Ruiz-Rejon M, GarridoRamos MA, RuizRejon F. Angiotensin-converting enzyme and p22(phox) polymorphisms and the risk of coronary heart disease in a low-risk Spanish population. Int J Cardiol. 2004;95(2-3):145-51.

26. Hooper WC, Dowling NF, Wenger NK, Dilley A, Ellingsen D, Evatt BL. Relationship of venous thromboembolism and myocardial infarction with the reninangiotensin system in African-Americans. Am J Hematol. 2002;70(1):1-8.

27. Fukazawa R, Sonobe T, Hamamoto K, Hamaoka K, Sakata K, Asano T, Imai T, Kamisago M, Ohkubo T, Uchikoba Y, Ikegami E, Watanabe M, Ogawa S. Possible synergic effect of angiotensin-I converting enzyme gene insertion/deletion polymorphism and angiotensin-II type-1 receptor $1166 \mathrm{~A} / \mathrm{C}$ gene polymorphism on ischemic heart disease in patients with Kawasaki disease. Pediatr Res. 2004;56(4):597-601.

28. Karaali ZE, Agachan B, Yilmaz H, Isbir T. Angiotensin-converting enzyme I/D gene polymorphisms and effects of left ventricular hypertrophy in Turkish myocardial infarction patients. Acta Cardiol. 2004;59(5):493-7.

29. Arca M, Pannitteri G, Campana F, Candeloro A, Montali A, Cantini R, Seccareccia F, Campa PP, Marino B, Ricci G. Angiotensin-converting enzyme gene polymorphism is not associated with coronary atherosclerosis and myocardial infarction in a sample of Italian patients. Eur J Clin Investig. 1998:28:485-90.

30. Ludwig E, Corneli PS, Anderson JL, Marshall HW, Lalouel JM, Ward RH. Angiotensin-converting enzyme gene polymorphism is associated with myocardial infarction but not with development of coronary stenosis. Circulation. 1995;91:2120-4

31. Jenemaitre X, Ledru F, Battaglia S, et al. Genetic polymorphism of the renin-angiotensin system and angiographic extent and severity of coronary artery disease: the CORGENE study. Hum Genet. 1997;99:66-73.

32. FriedI W, Krempler F, Paulweber B, Pichler M, Sandhofer F. A deletion polymorphism in the angiotensin converting enzyme gene is not associated with coronary heart disease in an Austrian population. Atherosclerosis. 1995:112:137-43. 
33. Winkelman BR, Nauck M, Klein B, et al. Deletion polymorphism of the angiotensin converting enzyme gene is associated with increased plasma angiotensin converting enzyme activity, but not with increased risk of myocardial infarction and coronary artery disease. Ann Intern Med. 1996:125:19-25.

34. Lachurie ML, Azizi M, Guyene TT, Alhenc-Gelas F, Menard J. Angiotensinconverting enzyme gene polymorphism has no influence on the circulating renin-angiotensin-aldosterone system or blood pressure in normotensive patients. Circulation. 1995;91:2933-42.

35. Harrap S, Davidson HR, Connor JM, Soubrier F, Corvol P, Fraser R. The angiotensin I converting enzyme gene and predisposition to high blood pressure hypertension. Hypertension. 1993;21:455-60.

36. Itoh H, Mukoyama M, Pratt RE, Gibbons GH, Dzau VJ. Multiple autocrine growth factors modulate smooth muscle cell growth response to angiotensin II. J Clin Investig. 1993;91:2268-74.

37. Gesiterper AAT, Peach MJ, Owens GK. Angiotensin II induces hypertrophy not hyperplasia of cultured rat aortic smooth muscle cells. Circ Res. 1988;62:749-56.

38. Gibbons GH, Pratt RE, Dzau VJ. Vascular smooth muscle cell hypertrophy vs hyperplasia: autocrine transforming factors $\$ 1$ expression determines growth response to angiotensin II. J Clin Investig. 1992;90:456-61.

39. Mattu RK, Needham EWA, Galton DJ, Frangos E, Clark AJL, Caulfield MC. A DNA variant at the angiotensin-converting enzyme gene locus associated with coronary artery disease in the Caerphilly Heart Study. Circulation. 1995;91:270-4
40. Nakai K, Itoh C, Miura Y, et al. Deletion polymorphism of the angiotensin I converting enzyme gene is associated with serum ACE concentration and increased risk for CAD in the Japanese. Circulation. 1994;90:2199-202.

41. Leatham E, Barley J, Redwood S, et al. Angiotensin-1 converting enzyme (ACE) polymorphism in patients presenting myocardial infarction or unstable angina. J Hum Hypertens. 1994;8:635-8.

42. Lindpaintner K, Lee M, Larson MG, Rao VS, Pfeffer MA, Ordovas JM, Schaefer EJ, Wilson AF, Wilson PW, Vasan RS, Myers RH, Levy D. Absence of association or genetic linkage between the angiotensinconverting-enzyme gene and left ventricular mass. N Engl J Med. 1996;334(16):1023-8.

43. Miettinen HE, Korpela K, Hamalainen L, Kontula K. Polymorphism of the apolipoprotein and angiotensin converting enzyme genes in young North Karelian patients with coronary heart disease. Hum Genet. 1994;94:189-92.

44. Agerholm-Larsen B, Nordestgaard BG, Steffensen R, Sorensen TIA, The Copenhagen City Heart Study Group. The angiotensin-convertingenzyme gene polymorphism fails to predict coronary heart disease in a case-cohort study of 7300 individuals (abstract). Circulation. 1995;92(Suppl. I):800.

45. Samani NJ, Thompson JR, O'toole L, Channer K, Woods KL. A meta-analysis of the association of the deletion allele of the angiotensin-converting enzyme gene with myocardial infarction. Circulation. 1996;94:708-12.

\section{Submit your next manuscript to BioMed Central and we will help you at every step:}

- We accept pre-submission inquiries

- Our selector tool helps you to find the most relevant journal

- We provide round the clock customer support

- Convenient online submission

- Thorough peer review

- Inclusion in PubMed and all major indexing services

- Maximum visibility for your research

Submit your manuscript at www.biomedcentral.com/submit 